TWO THEORIES OF MONEY RECONCILED:

THE COLONIAL PUZZLE REVISITED WITH NEW EVIDENCE

\author{
Farley Grubb
}

Working Paper 11784 
NBER WORKING PAPER SERIES

\title{
TWO THEORIES OF MONEY RECONCILED: THE COLONIAL PUZZLE REVISITED WITH NEW EVIDENCE
}

\author{
Farley Grubb
}

Working Paper 11784

http://www.nber.org/papers/w11784

\author{
NATIONAL BUREAU OF ECONOMIC RESEARCH \\ 1050 Massachusetts Avenue \\ Cambridge, MA 02138 \\ November 2005
}

The author is Professor of Economics and NBER Research Associate, University of Delaware, Newark, DE 19716 USA. http://myprofile.cos.com/grubbf16; grubbf@lerner.udel.edu. Earlier versions were presented at the Columbia University, Northwestern University, the University of Delaware, and at the 2001 National Bureau of Economic Research Development of the American Economy Summer Institute. The author thanks the participants at these seminars and Burt Abrams, Edwin Perkins, David Stockman, and Peter Temin for helpful comments. Mark Mylin and Anne Pfaelzer de Ortiz provided research, and Anne Pfaelzer de Ortiz provided editorial assistance. The views expressed herein are those of the author(s) and do not necessarily reflect the views of the National Bureau of Economic Research.

(O2005 by Farley Grubb. All rights reserved. Short sections of text, not to exceed two paragraphs, may be quoted without explicit permission provided that full credit, including $\odot$ notice, is given to the source. 
Two Theories of Money Reconciled: The Colonial Puzzle Revisited with New Evidence Farley Grubb

NBER Working Paper No. 11784

November 2005

JEL No. N11, E42

\begin{abstract}
The purported failure of the classical quantity theory of money in the colonial economy is shown to be a failure of data and not a failure of theory. When new data on the quantity of specie in circulation is added to the current data on paper money and prices, and econometrically estimated in both shortand long-run monetary models, the long-debated anomaly regarding the performance of the classical quantity theory of money in the colonial economy disappears. How paper money was backed and could be exchanged for specie was important, but not in the way theorists assert.

Farley Grubb

University of Delaware

Economics Department

Newark, DE 19716

and NBER

grubbf@lerner.udel.edu
\end{abstract}




\section{Two Theories of Money Reconciled: The Colonial Puzzle}

\section{Revisited with New Evidence*}

The purported failure of the classical quantity theory of money in the colonial economy is shown to be a failure of data and not a failure of theory. When new data on the quantity of specie in circulation is added to the current data on paper money and prices, and econometrically estimated in both short- and long-run monetary models, the long-debated anomaly regarding the performance of the classical quantity theory of money in the colonial economy disappears. How paper money was backed and could be exchanged for specie was important, but not in the way theorists assert. (JEL N11 E42)

The colonies of British North America were the first modern Western economies to experiment with large-scale government issuances of fiat paper money. For colonies south of Massachusetts, West (1978) found no statistical relationship between the quantity of paper money and prices. This apparent violation of the classical version of the quantity theory of money (Fisher 1912, Friedman 1956, Lucas 1980) produced two schools of thought regarding paper money in colonial America. "Backing” theorists (Calomiris 1988a, 1988b; Smith 1985a, 1985b, 1988; Wicker 1985) argue that the value of paper money depends on how that money was issued, backed, and withdrawn from circulation. If credibly backed, large changes in the quantity of paper money would have no effect on prices. Conversely, "quantity" theorists (McCallum 1992; Michener 1987, 1988) note that a colony's total money supply was composed of both paper money issued by that colony's legislature and specie coins acquired and lost through foreign trade ( $M T=M p+M s$, respectively). They also claim that $M p$ and $M s$ were perfect substitutes. Any lack of a statistical relationship between $M p$ and prices may have been due to currency substitution between $M p$ and $M s$. If $M T$ were related to prices, the classical quantity theory of money might still hold. However, because no continuous quantitative data on $M s$, and 
hence $M T$, exist, the debate between these two schools of thought has remained unresolved. ${ }^{1}$

In this study, I use new data on $M s$ per year in Pennsylvania - the first of its kind ever constructed for colonial America - to test the performance of the quantity theory of money using $M T$ rather than $M p$. These tests show that the classical version of the quantity theory of money performs well. The data also show that while the "quantity" theorists are correct, it is not via the mechanism they claim. As such, the monetary experience of colonial America, at least for Pennsylvania, presents no anomaly to the classical quantity theory of money (Fisher 1912, Friedman 1956, Lucas 1980). There is a strong long-run relationship between money and prices, but in the short-run large temporary movements in aggregate output $(Y)$ and velocity $(V)$ are still possible.

\section{RETESTING THE WEST (1978) SHORT-RUN MODEL}

Following the classical assumptions of constant long-run growth in $Y$ and $V$, West (1978) estimated the model $\left[\ln (P I)_{\mathrm{i}}=\right.$ Constant $\left.+b^{*} \ln (M p)_{\mathrm{i}}\right]$, where $P I=$ the price index. For New York, Pennsylvania, and South Carolina (the only colonies south of Massachusetts for which price indices exist), even when adding up to two lagged values of $M p$, he found no statistically significant relationship between $P I$ and $M p$. The lack of a statistically significant relationship between $P I$ and $M p$ for New York and South Carolina could easily be due to poor-quality price data and small sample sizes. The data for Pennsylvania, however, are generally regarded to be of superior quality. As such, the lack of a statistically significant relationship between $P I$ and $M p$ for Pennsylvania is the empirical cornerstone for the current puzzle over colonial monetary performance. West's results for Pennsylvania are reproduced in Table 1 -Section I, Part A. He (1978, p. 5) concluded, “The Philadelphia regressions are interesting and important. They cover the whole history of paper money in the colony. From the year paper money was first issued, 
1723, until 1775, inflation and the issue of paper money seems to be unrelated. One can place great confidence in these results since the price data for Philadelphia are very good." 2

$$
\text { [Place Table 1 Here] }
$$

Using the same model and data, West's (1978) results for Pennsylvania were replicated in Table 1-Section I, Part B. While the results differ from those originally reported by West, they do not differ enough to necessarily overturn his conclusion. ${ }^{3}$ Next, West's model is reestimated using $M T$ in place of $M p$, see Table 1 - Section II. Slightly different years must be used because $M s$, and hence $M T$, is only known for 1729 through 1775 . This difference does not affect the results. Compared with the results using only $M p$, the relationship between $P I$ and $M T$ is substantially improved, i.e., substantially higher $\mathrm{R}^{2} \mathrm{~s}$ and statistical significance on the money coefficients. While these results are not overwhelming, they are still strong given that this model is a short-run test of a long-run proposition. No one claims that $\ln (Y)$ and $\ln (V)$ are universal constants with no short-run cyclical movements, i.e., no one claims that $b$ must equal 1 for the classical version of the quantity theory of money to hold (Friedman 1956; Lucas 1980, p. 1007). If West had reported the results using $M T$ in Table $1-$ Section II, it is likely that the subsequent debate between the "quantity" and the "backing" theorists over colonial monetary performance would never have occurred.

\section{LONG-RUN TESTS OF THE QUANTITY THEORY OF MONEY}

The West (1978) model is an improper test of the classical quantity theory of money because it is a short-run model (Friedman 1956; Lucas 1980, p. 1007; McCallum 1992, p. 157). The classical assumptions that per capita $\ln (Y)$ and $\ln (V)$ are long-run constants implies that money demand or per capita total real money balances $\left(m=\ln \left[M T /\left(P^{*} P o p\right)\right]\right.$ where $P$ is the price 
level and Pop is population) is stable over the long-run, but not necessarily in the short-run. Per capita real money balances from 1729 through 1775 for Pennsylvania are displayed in Figure 1. Using these data, the following regression shows that $m$ has no linear trend. Over the long run, total real money balances grew at the rate of population.

$$
m_{(\mathrm{i})}=\begin{array}{cl}
0.347+0.002 t_{\mathrm{i})} & \begin{array}{l}
\text { Regression } \mathrm{R}^{2}=0.002 ; \text { Total } \mathrm{R}^{2}=0.821 ; D W=1.889 . \\
(0.203) \quad(0.008)
\end{array} \\
& \begin{array}{l}
\text { Standard errors are in parentheses. Results are AR2 error } \\
\text { corrected for serial correlation. } t=\text { time. }
\end{array}
\end{array}
$$

This result also implies that long-run per capita growth in colonial output equals the long-run growth in the velocity of circulation, i.e., $\ln (Y / P o p)=\ln (V)$. Finally, the following Augmented Dickey-Fuller test shows that $m$ follows a stationary process. Shocks to $m$ experienced mean reversion — with about a three-year half-life to shocks. This long-run stability in $m$ strongly

$$
\begin{aligned}
& {\left[m_{(\mathrm{i})}-m_{(\mathrm{i}-1)}\right]=0.081-0.218 m_{(\mathrm{i}-1)}+0.620\left[m_{(\mathrm{i}-1)}-m_{(\mathrm{i}-2)}\right]} \\
& \text { (0.033) (0.069) (0.132) }
\end{aligned}
$$

supports the classical version of the quantity theory of money as applied to the colonial economy, at least for Pennsylvania.

[Place Figure 1 Here]

\section{ASSESSING THE MECHANISMS OF ADJUSTMENT IN THE COLONIAL ECONOMY}

\section{A. The "Quantity" Theorists' Model of the Monetary Adjustment Mechanism}

The "quantity" theorists (McCallum 1992; Michener 1987, 1988) offer a model of the monetary adjustment mechanism in the colonial economy that assumes that $M p$ and $M S$ are instantaneously perfect substitutes at a perfectly defended and forecastable fixed exchange rate with zero transactions costs. As long as increases in $M p$ are not so large that they totally drive $M s$ out of the colony, changes in $M p$ would be perfectly off-set by opposite flows (imports and 
exports) of $M s$ leaving $M T$ unchanged. Thus, even large changes in $M p$ can be unrelated to $P I$ because $M T$ per capita remains constant. As such, West (1978) style findings that show no relationship between $P I$ and $M p$ support rather than violate the classical quantity theory of money. Only when increases in $M p$ have totally driven all $M s$ out of the colony would further increases in $M p$ produce increases in PI. These scholars claim to have saved, at least theoretically, the classical quantity theory of money from the challenges put forward by the "backing" theorists and by the West (1978) style findings. However, they have saved it by rendering it useless as an empirical tool for colony-specific or even regionally-specific monetary analysis - for in their model only the global money supply matters.

The institutional setting needed to support the required action in this model, however, is absent. How the model's assumed fixed exchange rate between $M p$ and $M s$ was defended remains a mystery (Smith 1988). While colonial governments accepted specie and their own paper money in payment of the taxes they levied at an established rate, what made this rate, which could be altered at any time by the legislature, equivalent to a perfectly defended fixed exchange rate regime is unclear. Colonial legislatures did not and could not engage in monetary micro-management in the very short-run (certainly not like modern central banks). They never entered the market to buy and sell their paper money for specie neither to affect nor in reaction to exchange rate movements. And to assume that such a fixed exchange rate regime was perfectly defended by custom or by a conspiracy of myopic merchant-arbitragers stretches credulity. ${ }^{6}$

The fixed exchange rate assumption of the quantity theorists is also hard to square with the available data on exchange rates (McCusker 1978). These data are based on the rates stated in a large sample of merchant account books between pounds sterling and each colony's paper money. It reveals considerable variation in each colony's rate over time. The monthly data from 
1740 through 1775 for Pennsylvania are probably the best in terms of frequency, density, and quality of observations (McCusker 1978, pp. 185-88). For the 432 months over these 36 years, data for only 34 months is missing, and the missing observations are widely scattered. These data reveal that in only $11 \%$ of the possible paired comparisons were the exchange rates in a given month the same as in the subsequent month. And in only $4 \%$ of the possible paired comparisons were the exchange rates in a given month the same as in the same month in the subsequent year. Clearly, the exchange rate was not fixed. Grubb (2003, p. 1786), however, shows that despite this volatility, several colonies experienced periods of long-run stability in their exchange rates in terms of statistically insignificant linear trends and statistical rejection of non-stationarity. But just as periods of constant prices do not imply price controls, periods of relative stability in exchange rates do not imply a fixed exchange-rate regime. The long-run stability of these exchange rates can be easily accounted for by the lack of trend in, and by the stationary behavior of, per capita real money balances (see the prior section). The quantity theorists have simply confused exchange-rate stability for exchange-rate fixedness.

Finally, the predictions of the quantity theorists' model of the monetary adjustment mechanism have not, to date, been tested because evidence on the yearly amount of $M s$ in circulation has been lacking. These predictions are that $M p$ and $M s$ per capita are perfectly negatively correlated, and that $M s$ must dwarf $M p$, i.e., $M s / M p>1$, by a substantial margin for $P I$ to remain unrelated to $M p$ given the observed large movements in $M p$. With the new data series on Ms for Pennsylvania (Grubb 2004) both these implications can now be tested and, when tested, they both fail. First, $M s$ never exceeds $M p$ in any year in the sample (see the data in the Appendix-Table A). Second, over time $M p$ and $M s$ are far from automatically off setting (see Figure 1 and the data in the Appendix-Table A). $M p$ and $M s$ even co-vary positively 
during the Seven Year's War and after 1772. In fact, for the entire sample, 1729-1775, the correlation coefficient between per capita cash balances in $M p$ and in $M s$ is not negative, but positive (+0.47). Only for the years $1762-1772$ do per capita $M p$ and $M s$ come close to behaving like perfect substitutes, with a correlation coefficient in this period of -0.71 . For the years before 1762 and after 1772 combined, the correlation coefficient is $+0.51 .^{7}$

The problem with the quantity theorists' model of the monetary adjustment mechanism is that it constrains the classical version of the quantity theory of money to hold perfectly in the short-run, something it was never intended to do. As such, the model falls victim to the actual course of events. The history of the colonial economy reveals frequent, and sometimes massive, short-run off-trend shocks connected to wars, political trade disruptions, and so forth. For example, the Seven Year's War occasioned both a massive increase in $M p$ by colonial legislatures and a large inflow of $M s$ occasioned by British military spending, see Figure 1 above. The colonial response to the British credit crisis of 1772 (legislative increases in $M p$ ), and to British efforts to impose imperial taxes and close Boston harbor (boycotting the import of British goods thus reducing the re-export of $M s$ out of the colonies) had a similar result. It led to simultaneous increases in $M p$ and $M s$. While the econometric exercises in the prior sections show that the classical version of quantity theory of money performs well in the colonial economy, substantial short-run off-trend shocks clearly occurred.

In conclusion, the currency-substitution claims made by the quantity theorists are too simplistic to account for the empirical evidence. The same evidence shows both that the classical quantity theory of money performs well, and that the quantity theorists' model of the monetary adjustment mechanism fails. Therefore, the quantity theorists' model of the monetary adjustment mechanism is not needed to save the classical quantity theory of money in the colonial economy. 


\section{B. The “Backing” Theorists' Model of the Monetary Adjustment Mechanism}

The "backing" theorists' (Calomiris 1988a, 1988b; Smith 1985a, 1985b, 1988; Wicker 1985 ) model of the colonial monetary adjustment mechanism makes $V$ a direct negative function of $M p$. As such, increases in $M p$ can be perfectly offset by reductions in $V$, and vice versa, so that $P I$ remains unrelated to changes in $M p$. This assumption contrasts sharply with the classical quantity theory of money that assumes that $V$ is not a direct function of $M T$ in either the short or long run. At best, $V$ might be an indirect function of $M T$, but only in the short-run through $M T$ 's transitional or cyclical effect on $P$ and interest rates (Cagan 1956, Fisher 1912, Friedman 1956). Given that the econometric exercises in the prior sections show that the classical quantity theory of money performs well in the colonial economy, especially in the long-run where $\ln (V)$ is assumed to be a constant, the backing theorists' model of the monetary adjustment mechanism is only relevant for explaining off-trend or short-run cyclical movements.

On some margins the institutional setting needed to support the required action in this model is present, while on other margins it is not. For example, the institutional setting for the injection and removal of $M p$ is consistent with backing theory. Colonial governments issued $M p$ in conjunction with specific taxes designed to redeem said $M p$ at future established dates, or as loans to subjects who pledged their land as collateral and adhered to specific repayment schedules (Behrens 1923, Brock 1975, Wicker 1985). Colonists could have forecast whether these future conditions were likely to be fulfilled. By institutionally linking current monetary action with future monetary action, and assuming that colonists could fully anticipate both current and future monetary actions, colonists could engage in inter-temporal shifts in savings and consumption that would fully undo current monetary action (Barro 1977, Sargent and 
Wallace 1981). One avenue of response would be for colonists to increase their cash holdings (decreasing $V$ ) when a colony increased its $M p$ in anticipation of paying the future taxes and mortgage payments that were directly tied to that current increase in $M p$. Another avenue of response would be for colonists to increase their cash holdings (decreasing $V$ ) when a colony increased its $M p$ in anticipation of lower future prices produced by the required future reduction (redemption) of said $M p$. This action would in turn prevent the current increase in $M p$ from pushing up current prices. Thus, unlike the 19th and early 20th centuries, the colonial institutional setting may have caused $V$ to be a direct negative function of $M p .^{8}$

On the other hand, whether $M p$ served as a vehicle for inter-temporal shifts in savings and consumption in the colonial economy is doubtful. For large changes in $M p$ to be completely absorbed by changes in $V$ implies large changes in the holding of real cash balances. Because government bonds and deposit banking do not exit in the colonial economy, this possibility relies on the personal possession of cash being an important asset or store of value rather than just a medium of exchange (Laidler 1987, Sargent and Wallace 1981). However, evidence from probate inventories shows that possession of cash comprised only $2.4 \%$ of total net worth (Jones 1980, pp. 128-29). The vast majority of wealth was held as land, and the vast majority of financial assets were held in non-marketable debt claims. Cash served principally as a medium of exchange and not as a store of value. The circulation of $M p$ was so frequent that Pennsylvania's legislature had to pass, and often renew, an act authorizing the exchange "torn and ragged" bills for new bills (Statutes at Large, vol. 4, pp. 203, 414; vol. 5, pp. 48, 60, 192; vol. 7, p. 204). The prerequisite of substantial personal asset-holdings of cash needed for the backing theory's monetary mechanism to work does not appear to have been met by the colonial economy. In addition, whether current and future monetary actions could be fully anticipated by 
colonists is doubtful. The assumption that colonists could fully anticipate monetary actions is necessary to eliminate the possibility that money is non-neutral in the short run (Barro 1977). If money is neutral in the short run, then changes in $M T$ can only change $P$ or $V$ in the short run. The institutional setting in the backing theory eliminates $P$, thus leaving only $V$ to change in the short run. However, if colonists could not fully anticipate monetary actions, then the nonneutrality of money in the short run is restored. In 1764 Benjamin Franklin observed that injections of paper money "gave new life to business" and "promoted greatly the settlement of new land" (Nussbaum 1957, p. 27). This raises the possibility that changes in $M T$ caused shortrun changes in $Y$ rather than $V$, a possibility that backing theory can only eliminate in the colonial economy by assumption.

Colonial legislatures engaged in substantive monetary actions in response to large crises, such as wars, depression, and trade shocks (Brock 1975, pp. 74-84, 353-91; Lester 1938; Pennsylvania Archives; Statutes at Large of Pennsylvania). Wars and trade shocks were known to be likely near-term events, though exactly when they would occur was not easy to anticipate. They were certainly unforecastable five years out. Once a crisis was upon a colony, anticipating the course of monetary injections was also difficult. For example, during the Seven Year's War, while colonial legislatures typically authorized the issuance of a given sum of $M p$, the actual injection of money into the economy to pay soldiers, etc. occurred as needed (Appendix-Table B). In addition, because the timing of future new injections of $M p$ were not contingent on present monetary actions, the exact time-path of future $M T$, despite the required redemption of current $M p$ injections, could not be fully anticipated. Finally, because these monetary injections were typically government spending - money put in the hands of soldiers who were non-saversshort-run changes in $Y$ would seem likely. 
Figure 1 shows the existence of large short-run cyclical or off-trend movements in total real cash balances per capita- $\ln \left[M T /\left(P^{*} P o p\right)\right]$. This is identical to showing large off-trend movements in $[\ln (Y / P o p)-\ln (V)]$. But because direct credible yearly time series on $Y$ and on $V$ do not currently exist, determining what share of this off-trend movement is due to $V$ 's response to $M T$ as opposed to movements in $Y$ is currently impossible. The backing theorists' primary empirical test involves finding periods where $[\ln (M p / P)]$ changed by large magnitudes, asserting that $\ln (M s)$ is unimportant and that $\ln (Y)$ could not conceivably have changed by such a magnitude, and then concluding, by deduction, that substantial changes in $\ln (V)$ must have occurred. Evidence from the Seven Year's War provides their key empirical test example (Smith 1985a, 1988; Wicker 1985). Between 1754 and 1759, total real cash balances per capita in Pennsylvania, for example, increased by 147\% (see Figure 1 and Appendix-Table A). On the surface, the possibility that per capita $Y$ could increase by $147 \%$ over a five-year period seems highly improbable. Thus, by deduction, $V$ must have decreased by a substantial percentage. This reasoning, however, fails to appreciate the colossal and unprecedented effect the Seven Year's War had on real aggregates as well as on monetary aggregates. For example, between 1754 and 1759, the value of British exports to the Thirteen Colonies increased by $69 \%$, and the value of British export to, minus imports from, the Thirteen Colonies increased by an overwhelming 232\% (derived from Egnal 1998, p. 35; Mitchell and Deane 1962, p. 310). The colonies experienced a massive influx and net retention of goods during these five years. The first half of the Seven Year's War, therefore, occasioned both an unprecedented increase in $[\ln (M T / P)]$ and an unprecedented increase in $\ln (Y)$ of potentially similar magnitudes. Finally, as the War ended and $[\ln (M T / P)]$ declined precipitously (see Figure 1), $Y$ also declined to depression levels (Egnal 1998, pp. 42-117; Doerflinger 1986, pp. 173-78; McCusker and Menard 1985, p. 63). This 
movement in $Y$ could have left little room for the changes in $V$ required by backing theory. Likewise, substantial short-run cyclical changes in $Y$ occurred during the Revolutionary War (Buel 1998, Doerflinger 1986, O’Shaughnessy 2000), which makes assessing backing theory outcomes during the Revolution (Calomiris 1988a) problematic.

In conclusion, if monetary shocks were largely reflected through $Y$ in the short run and total real money balances per capita remained constant in the long run, then we are back in a classical quantity theory of money world. Until more is known about the exact magnitudes of year-to-year changes in $Y$ and $V$, the backing theory's mechanism of monetary adjustment as applied to the colonial economy must remain speculative.

\section{SMITH'S DIRECT ECONOMETRIC TEST OF BACKING VERSUS QUANTITY}

Maryland's paper money emission and method of backing for the years 1733 through 1764 were unique. In 1733 Maryland authorized the issuance of 90,000 Maryland pounds in bills of credit (paper money). The quantity of bills in circulation at any one time was less than this authorized sum by varying amounts, see Appendix - Table B. While other colonies backed their paper money with future taxes and land mortgages, Maryland's bills were backed through the creation of a sinking fund. The money for this fund came from the proceeds of a 15 pence tax on every hogshead of tobacco exported from the colony, and was used to purchase Bank of England stock. This fund was to be used to redeem the bills in two stages, in each case by converting a sufficient amount of the sinking fund into sterling bills of exchange and exchanging them for Maryland pounds at a rate of three pounds sterling for every four Maryland pounds. This rate was considered the par exchange rate between sterling and Maryland currency. One-third of the bills were to be redeemed in 1748. The two-thirds not redeemed in 1748 were to be exchanged at that date for new bills that were then to be redeemed in 1764 in the same fashion as in 1748 . 
Maryland's sinking fund provides a yearly measure of the current value of what backed Maryland's paper money (Behrens 1923, pp. 12-49; Brock 1975, pp. 99-105, 412-28; Price 1977) ${ }^{9}$

Smith (1985b, pp. 1200-08) used the unique features of Maryland's monetary system to craft a direct econometric test between the quantity of paper money and the backing of paper money to see which played a greater role in determining the value of paper money. Smith's test is the only econometric and statistical exercise published after West (1978) on the debate over backing versus the quantity of money in the colonial economy. Because Maryland's backing provision consisted of an explicit commitment to swap sterling for Maryland pounds, Smith used the yearly data on the sterling-to-Maryland pound exchange rate (McCusker 1978, pp. 202-03) to measure changes in the value of the Maryland pound. Given the absence of a commodity price index and information on the amount of specie in circulation for Maryland, there was no alternative measure. Smith regressed the deviation of the exchange rate from $\operatorname{par}\left[\operatorname{Par}_{(i)}\right]$ on the quantity of bills actually in circulation $\left[M M S p_{(i)}\right]$, the routine yearly operation of the backing regime as measured by the current size of the sinking fund relative to its final size in 1764 $\left[F_{(i)} / F_{(1764)}\right]$, and the credibility of the promise to redeem these bills at par as measured by whether Maryland kept its intermediate redemption promise in 1748 [ $\left.D_{1748-64}\right]$. Smith's results are reproduced in Table 2-Section I, Part A. Based on these results, Smith (1985b, pp. 1207-08) concluded that "Clearly the quantity of money alone has no impact on currency value....[I]ncreases in the market value of the backing for notes result in an appreciation in the value of Maryland currency....[A] history of honoring promised redemptions... enhance[s] their value." Smith's results, however, are a product of peculiar data interpolations and inappropriate theoretical and econometric interpretations. When these problems are corrected, his conclusions 
fail to stand.

[Place Table 2 Here]

First, Smith's results are replicated, using his data and model, to make sure that the subsequent analysis starts from the same point and the subsequent differences in results are purely a product of the changes described. Table 2 - Section I, Part B - shows that the data and model used here can replicate Smith's results. ${ }^{10}$ Second, Smith's test for whether Maryland's honoring of its redemption commitment in 1748 affected the exchange rate is examined. $\mathrm{He}$ modeled this effect by breaking the sample at 1748 and seeing if the years 1748-1764 were different than the years $1735-1747$ [the $D_{1748-64}$ dummy variable]. The same results, however, can be obtained when breaking the sample at any year between 1744 and 1756. In fact, the best econometric result is obtained by dividing the sample at 1744 rather than at 1748 . Two of these alternative regressions are reported in Table 2 -Section I, Part C. ${ }^{11}$ Thus, Smith's result is not distinctly an outcome of his hypothesis; a large number of alternative hypotheses could yield the same result, such as shocks caused by the beginning or ending of major wars (see Figure 1). Maryland's fulfillment of its redemption commitment in 1748 had no effect on the exchange rate distinguishable from any number of other events occurring in the five years on either side of 1748. Therefore, this measure of backing can be discarded. It lacks statistical and interpretive relevance.

The third step examines Smith's measure of the quantity of money in circulation $[M M S p]$. Smith's measure relies on extensive data interpolation. Of the 30 years of data on this variable, 18 are not observations but interpolations (the bracketed numbers in Appendix-Table B). In the years before 1756, Smith filled in missing observations with the immediately prior observation, and filled in missing observations after 1755 by substituting the authorized amount 
for the amount actually in circulation. Smith neither indicated that his data were highly interpolated nor offered any justification for his peculiar method of data interpolation. Based on the discussions in the original source (Brock 1975, pp. 104, 418-19) I constructed an alternative set of interpolated values $[M M G p]$, see Appendix-Table B. Simple linear interpolated values are used in place of Smith's use of immediately prior observations for missing values before 1756. The paper money authorized in 1756 was put into circulation slowly and then taxed out of circulation by 1763 . To capture this effect, I used two separate linear interpolations, one from 1755 to 1759 and another from 1759 to 1764 , in place of Smith's use of the authorized amount, for missing values after 1755. When $M M G p$ is used in Smith's regression model in place of MMSp a statistically significant relationship between the quantity of money and Par appears, see Table 2-Section II, Part A. Smith's (1985b, p. 1207) conclusion, using his econometric standards, that "Clearly the quantity of money alone has no impact on currency value...", is overturned. This result is achieved even without adding the specie component to Maryland's money supply, which is currently unknown, as was done for Pennsylvania above.

The final step examines Smith's empirical measure of Maryland's backing regime- the sinking fund's value in a given year as a percentage of its final value in 1764. The theoretical motivation for this empirical measure lacks clarity. Just because a particular backing regime succeeds in replacing the money-price relationship with a money-velocity relationship, it does not follow, theoretically, that the routine operation of that regime should be related to changes in prices or exchange rates. Smith's interpretation of his econometric model as a horse race between the backing of money and the quantity of money as to which determines the value of money, therefore, lacks cogency.

Alternatively, if Smith's intention was to measure not the routine operation of the 
backing regime, but the likelihood that Maryland would experience a backing regime shift in 1764 , then his measure of backing $\left[F_{(i)} / F_{(1764)}\right]$ lacks empirical cogency for it does not capture subjects' expectations in any year about whether Maryland would be able to meet its promised redemptions. For example, Maryland would be able to fully redeem its paper money as promised in 1748 and 1764, i.e., its paper money would be fully backed, if it were accumulating sufficient money each year in its sinking fund so that by 1748 and 1764 it could cover the promised redemption. Deviations from this perfect-backing level of accumulation bare little relationship to Smith's measure $\left[F_{(i)} / F_{(1764)}\right]$. A measure of the degree of backing credibility that would capture this expectation would be the deviation from the expected trend accumulation needed to just meet the promised redemption. The greater the sinking fund's deviation below this trend, the greater the expectation that Maryland would be forced to shift its backing regime, i.e., forced to redeem its paper money in 1764 at less than the promised three pounds sterling for every four Maryland pounds.

Several such measures were tried, but because all yielded the same result only one is reported, see Table 2-Section II, Part B. This measure [Forecasted Backing] equals the percentage the actual sinking fund at a given date fell below the linear accumulation rate needed to just fulfill the promised redemption in 1764. If Maryland were on this linear accumulation rate, they would also be able to fulfill their redemption promise of 1748 . This measure assumes that subjects knew how many of the bills authorized in 1733 the colony would eventually put into circulation. It also assumes that they knew that per-year tobacco exports, and so the tax revenue put into the sinking fund each year, would experience zero growth in the long run, and that the fund's stock dividends would largely be offset by commission fees. ${ }^{12}$ Thus, a linear accumulation rate in the sinking fund between 1733 and 1764 geared to meet the promised 
redemption of the actual sum to be redeemed in 1764 would correspond to perfect backing.

The sinking fund was substantially below this "perfect backing" trend accumulation in most years. For example, the fund was 50 percent below this trend accumulation in 1744 and again in 1758 . Only in 1749 , was it above and only after 1762 was it only 5 percent or less below, this trend accumulation. Maryland actually redeemed its paper currency as promised in 1748 and 1764 . They were able to do so because the sinking fund experienced exceptional growth in the years immediately prior to these redemption dates. This exceptional growth was in turn due to fortuitous peaks in tobacco exports and hence in the tax revenue contributions to the fund in 1747-48 and again in 1763-64 (Historical Statistics 1975, part 2, pp. 1189-90). It seems unlikely that Marylanders could have forecasted such luck.

If backing matters, and if subjects used the current accumulation trend in the sinking fund as the forecast of the likely end accumulation, then the coefficient on Forecasted Backing when used in the Smith-type model should be one. Par was three pounds sterling for every four Maryland pounds because Maryland promised to swap sterling for Maryland pounds at that rate in 1764. If the sinking fund in 1764 was, for example, 33.3 percent deficient, then Maryland could only swap two pounds sterling for every four Maryland pounds - a rate 33.3 percent below exchange par. Thus, if backing is what determines value, then the percentage the exchange rate was below par in a given year would be the same percentage by which the sinking fund in that year was below the trend accumulation needed to just meet the promised redemption in 1764 . The latter percentage was the percentage by which the sinking fund was forecasted to be deficient in 1764 .

When my measure of backing [Forecasted Backing] and money [MMGp] are used in place of Smith's measure of backing $\left[F_{(i)} / F_{(1764)}\right]$ and money $[M M S p]$ in Smith's model, the 
coefficients on both the quantity of paper money and the backing of paper money, by Smith's econometric standards, are statistically significant with the correct sign, see Table 2-Section II, Part B. However, the coefficient on Forecasted Backing, while positive, is far from one.

Therefore, backing, as defined by the forecasting of the likely backing regime shift, appears to be of little importance to determining the value of money in Maryland between 1733 and 1764 .

Finally, when this model, or any model in Table 2, is AR1 corrected for serial correlation, statistically significant results on both the money and the backing variables disappear. As such, the data for Maryland may not be strong enough to tell us anything about backing versus the quantity of money. ${ }^{13}$

\section{MUCH ADO ABOUT NOTHING}

In the literature on colonial monetary behavior what theoretically differentiates the role of backing from that of the quantity of money has not been well articulated. Fiat paper money, by definition, assumes some type of backing in order to hold its value above its opportunity value. Scarcity of paper alone cannot do it. If scarcity alone determined a money's value, then it would be a commodity money not a fiat money. Someone, typically the government, must be willing to accept fiat paper money for some commodity, service, or (tax) obligation at a rate above its opportunity value, such as above paper money's value as a bookmark or a fire-lighter. At this level of analysis, there is no "quantity of money" versus "backing of money" dichotomy. Even Fisher's (1912) world of the classical quantity theory of money assumes that banknotes were convertible on demand into gold. Likewise, the "quantity" theorists' monetary adjustment mechanism for the colonial economy discussed above assumes backing, namely, that someone was willing to exchange fiat paper money for specie at a fixed rate. In other words, the quantity theory of (fiat) money assumes a backing regime. 
How backing affects nominal values is presented in two ways. First, for a given quantity of fiat money, a change in how money is backed, i.e., a sudden regime shift might alter the value of the fiat money (Sargent 1982). It might also change the responsiveness of $P, Y$, and $V$ to changes in $M T$ through altering the degree by which future $M T$ can be anticipated. Second, a particular backing regime might dissolve the long-run money-price connection by substituting a long-run money-velocity connection in its place (Calomiris 1988a; Laidler 1987; Sargent and Wallace 1981; Smith 1985a, 1985b, 1988; Wicker 1985). These two ways tend to be conflated in the literature on colonial monetary behavior - for an example, see the analysis of Smith (1985b) in the prior section.

The first way is least controversial because it does not directly challenge the classical quantity theory of money. While the evidence for colonial America is not strong enough to support systematic econometric testing, it is highly suggestive that when colonial legislatures substantially changed their paper money backing regimes, holding the quantity of paper money constant, nominal values changed in the expected direction. For example, Smith (1985a, p. 552; 1985b, pp. 1189, 1197) identifies likely regime shifts for South Carolina in 1731, North Carolina in 1748 , and Massachusetts in 1749. Grubb (2003, p. 1786) identifies a likely regime shift for Virginia around 1764-1766. Calomiris (1988a) identifies backing regime shifts behind the Continental dollar during the Revolution. Massachusetts' regime shift consisted of going off fiat paper money, and South Carolina's regime shift consisted of being prohibited by Parliament from issuing any new paper money. The other regime shifts pre-revolution typically consisted of legislatures changing how they redeemed their paper money and what they would accept in payment of taxes. In some cases they switched between the policy of taxing the money out of circulation and physically burning it, and the policy of rolling-over issues of paper money as 
they where paid in as taxes (Brock 1975, pp. 33-34, 112-13, 120-23; Ernst 1973, pp. 63-75; Perkins 1991, p. 15).

One of the clearest demonstrations of this backing regime-shift effect is for Maryland in 1781. Maryland issued three distinguishable types of paper money, namely, "red" money, "black" money, and "state continental" money in 1780-81. The three monies were backed differently, some by future taxes and some by the expected sale of confiscated loyalist property, and they also traded at differing discounts off their face value. Since, by definition, the total quantity of money (all monies) in Maryland was the same relative to red, black, and state continental money at any point in time, it is differential backing that likely produced their differential discounts (Behrens 1923, pp. 69-77).

Most of the backing literature for colonial America, however, does not focus on regime shifts, but examines the purported absence of a money-price relationship while holding a particular backing regime constant (Smith 1985a, 1985b, 1988; Wicker 1985). Most of the colonies and periods examined, such as those of Pennsylvania and Maryland above, had constant de facto backing regimes through out. ${ }^{14}$ As such, this second way of interpreting how backing affected nominal values is more controversial. By stressing that it is the particular regime, and not the shift in that regime, that matters, it directly challenges the classical quantity theory of money by substituting a long-run money-velocity relationship for the classical quantity theory of money’s long-run money-price relationship (Laidler 1987, Sargent and Wallace 1981).

The problem with the above approach to backing is that colonial backing regimes served two functions concurrently. They served a backing function by holding the value of paper money above its opportunity value through paper money's acceptance for tax obligations, and a quantity function by influencing the quantity of money through the time-path of note redemption. Based 
on this discussion and using the evidence for Pennsylvania in Figure 1, an alternative monetary adjustment mechanism will be offered that combines the backing and quantity mechanisms. The Pennsylvania legislature could not engage in monetary micro-management in the very short run. They also could not defend an exchange rate between paper money and specie in the short run. However, they could and did engage in monetary actions in response to large crises, such as wars, depressions, and trade shocks (Brock 1975, pp. 74-84, 353-91; Lester 1938; Pennsylvania Archives; Statutes at Large of Pennsylvania). For example, see Pennsylvania's response to the Seven Year's War (Wicker 1985) and to the 1772 British Credit Crisis (Neal 1990, pp. 170-71; Sheridan 1960) illustrated in Figure 1. Wars and trade shocks were known to be likely near-term events, though exactly when they would occur was not easily anticipated. The Pennsylvania legislature wanted to have a short-run monetary policy to finance wars, and to counter depressions by stimulating $Y$, but also wanted a credible long-run price-stability policy. To accomplish this dual policy, they had to convince their subjects that non-crisis monetary policy would undo the unanticipated crisis-year monetary injections such that per capita real cash balances would remain constant in the long run. They accomplished this through explicitly tying crisis-year monetary injections to taxes and mortgage payments that would be paid in the nearfuture non-crisis years. While designed to remove from circulation the prior monetary injection, the exact time-path of said removal was hard to forecast. The legislature maintained the credibility of this commitment by letting real cash balances decline during non-crisis periods, some of which could be quite lengthy, e.g., see 1733-41, 1748-54, and 1762-72 in Figure 1.

The particular backing regimes used in colonial America were designed to control the quantity of money in the long run, and to provide credibility to this long-run commitment in the face of unanticipated short-run deviations during crisis periods. The backing of paper money and 
the quantity of paper money cannot be regarded as independent theories here. They are inseparable elements of a given institutional setting that attempted to control the quantity of money in the long run, but allow short-run monetary influence over $Y$. Whether changes in $V$ over the short-run happened to also undo some of the changes in MT as an unintended side effect of this monetary policy is still an open question.

\section{CONCLUSIONS}

The long-running debate over the purported failure of the classical quantity theory of money in the colonial economy is shown to be a failure of data rather than a failure of theory. Only Pennsylvania has enough high-quality data to support econometric testing. For this colony, when new data on the quantity of specie is added to the existing data on the quantity of paper money and estimated in short- and long-run monetary models, the purported failure of the classical quantity theory of money disappears. From 1729 through 1775, per capita total real money balances exhibited a stationary process with no trend. The backing theory of monetary performance, changes in $M T$ undone by changes in $V$, is potentially relevant only during shortrun cyclical movements. The data on short-run movements in $Y$ versus $V$, however, are insufficient to gage the magnitude or even the existence of such an effect in the colonial economy.

[Place Appendix-Tables A and B Here] 


\section{REFERENCES}

Archives of the State of New Jersey. 1 st series.

Barro, Robert J., "Unanticipated Money Growth and Unemployment in the United States." American Economic Review 67 (Mar. 1977), pp. 101-115.

Behrens, Kathryn L., "Paper Money in Maryland, 1727-1789.” Johns Hopkins University Studies in Historical and Political Science 41 (1923), pp. 9-98.

Bezanson, Anne, et al., Prices in Colonial Pennsylvania. Philadelphia: Univ. of Pennsylvania Press, 1935.

Brock, Leslie V., The Currency of the American Colonies, 1700-1764. New York: Arno Press, 1975.

Brock, Leslie V., “The Colonial Currency, Prices, and Exchange Rates.” Introductory Comments by Ron Michener. Essays in History 34 (1992), pp. 70-132.

Buel, Richard Jr., The Irons. New Haven, CT: Yale Univ. Press, 1998.

Cagan, Phillip, “The Monetary Dynamics of Hyperinflation.” In Friedman, Milton, ed., Studies in the Quantity Theory of Money. Chicago: Univ. of Chicago Press, 1956. Pp. 23-117.

Calomiris, Charles W., "Institutional Failure, Monetary Scarcity, and the Depreciation of the Continental." Journal of Economic History 48 (Mar. 1988a), pp. 47-68.

Calomiris, Charles W., "The Depreciation of the Continental: A Reply." Journal of Economic History 48 (Sept. 1988b), pp. 693-698.

Cole, Arthur Harrison, Wholesale Commodity Prices in the United States, 1700-1861. Cambridge, MA: Harvard Univ. Press, 1938.

Davis, Andrew McFarland, ed., Colonial Currency Reprints, 1682-1751, Vol. 4. New York: Augustus M. Kelly, 1964.

Doerflinger, Thomas M., A Vigorous Spirit of Enterprise. Chapel Hill, NC: Univ. of North Carolina Press, 1986.

Egnal, Marc. New World Economies. New York: Oxford Univ. Press, 1998.

Enders, Walter, Applied Econometric Time Series. New York: John Wily \& Sons, 1995.

Ernst, Joseph Albert, Money and Politics in America, 1755-1775. Chapel Hill, NC: Univ. of North Carolina Press, 1973. 
Fisher, Irving, The Purchasing Power of Money. New York: Macmillan, 1912.

Friedman, Milton, "A Monetary and Fiscal Framework for Economic Stability." American Economic Review 38 (June 1948), pp. 245-264.

Friedman, Milton, "The Quantity Theory of Money_A Restatement." In Friedman, Milton, ed., Studies in the Quantity Theory of Money. Chicago: Univ. of Chicago Press, 1956. Pp. 1-21.

Grubb, Farley, "The Circulating Medium of Exchange in Colonial Pennsylvania, 1729-1775: New Estimates of Monetary Composition, Performance, and Economic Growth." Explorations in Economic History 41 (Oct. 2004), pp. 329-360.

Grubb, Farley, "Creating the U.S. Dollar Currency Union, 1748-1811: A Quest for Monetary Stability or a Usurpation of State Sovereignty for Person Gain?" American Economic Review 93 (Dec. 2003), pp. 1778-1798.

Historical Statistics of the United States. Washington DC: U.S. Bureau of the Census, 1975.

Jones, Alice Hanson, Wealth of a Nation to Be. New York: Columbia Univ. Press, 1980.

Laidler, David, "Wicksell and Fisher on the "Backing" of Money and the Quantity Theory." Carnegie-Rochester Conference Series on Public Policy 27 (1987), pp. 325-334.

Lester, Richard, "Currency Issues to Overcome Depression in Pennsylvania, 1723 and 1729." Journal of Political Economy 46 (June 1938), pp. 324-375.

Lucas, Robert E. Jr., "Two Illustrations of the Quantity Theory of Money." American Economic Review 70 (Dec. 1980), pp. 1005-1014.

Marchione, Margherita, ed., Philip Mazzei: Selected Writings and Correspondence: Volume I, 1765-1788. Prato, Italy: Edizioni Del Palazzo, 1983.

Maryland Gazette. Various issues.

McCallum, Bennett T., "Money and Prices in Colonial America: A New Test of Competing Theories." Journal of Political Economy 100 (Feb. 1992), pp. 143-161.

McCusker, John J., Money and Exchange in Europe and America, 1600-1775. Chapel Hill, NC: Univ. of North Carolina Press, 1978.

McCusker, John J., and Menard, Russell R., The Economy of British America, 1607-1789. Chapel Hill, NC: Univ. of North Carolina Press, 1985.

Michener, Ronald, "Fixed Exchange Rates and the Quantity Theory in Colonial America." Carnegie-Rochester Conference Series on Public Policy 27 (1987), pp. 233-308. 
Michener, Ron, "Backing Theories and Currencies of Eighteenth-Century America: A Comment." Journal of Economic History 48 (Sept. 1988), pp. 682-692.

Mitchell, B. R., and Deane, Phyllis, Abstract of British Historical Statistics. New York: Cambridge Univ. Press, 1962.

Neal, Larry, The Rise of Financial Capitalism. New York: Cambridge Univ. Press, 1990.

Newell, Margaret Ellen, From Dependency to Independence. Ithaca, NY: Cornell Univ. Press, 1998.

Nussbaum, Arthur, A History of the Dollar. New York: Columbia Univ. Press, 1957.

O'Shaughnessy, Andrew Jackson, An Empire Divided. Philadelphia: Univ. of Pennsylvania Press, 2000.

Pennsylvania Archives. 8th Series.

Pennsylvania Gazette. Various issues.

Perkins, Edwin J., "Conflicting Views on Fiat Currency: Britain and its North American Colonies in the Eighteenth Century." Business History 33 (July 1991), pp. 8-30.

Perron, Pierre, "The Great Crash, the Oil Price Shock, and the Unit Root Hypothesis." Econometrica 57 (Nov. 1989), pp. 1361-1401.

Price, Jacob M., "The Maryland Bank Stock Case: British-American Financial and Political Relations Before and After the American Revolution." In Land, Aubrey C., Carr, Lois Green, and

Papenfuse, Edward C., eds., Law, Society, and Politics in Early Maryland. Baltimore: Johns Hopkins Univ. Press, 1977. Pp. 3-40.

Sargent, Thomas J., "The End of Four Big Inflations." In Hall, Robert E., ed., Inflation: Causes and Effects. Chicago: Univ. of Chicago Press, 1982. Pp. 41-97.

Sargent, Thomas J., and Wallace, Neil, "Some Unpleasant Monetarist Arithmetic." Quarterly Review, Federal Reserve Bank of Minneapolis 5 (Fall 1981), pp. 1-17.

Sheridan, Richard B., "The British Credit Crisis of 1772 and the American Colonies." Journal of Economic History 20 (June 1960), pp. 161-186.

Smith, Bruce, "American Colonial Monetary Regimes: The Failure of the Quantity Theory and Some Evidence in Favor of an Alternative View." Canadian Journal of Economics 18 (Aug. 1985a), pp. 531-565. 
Smith, Bruce, "Some Colonial Evidence on Two Theories of Money: Maryland and the Carolinas." Journal of Political Economy 93 (Dec. 1985b), pp. 1178-1211.

Smith, Bruce D., "The Relationship Between Money and Prices: Some Historical Evidence Reconsidered." Quarterly Review, Federal Reserve Bank of Minneapolis 12 (Summer 1988), pp. 18-32.

Statutes at Large of Pennsylvania, Vols. 1-8. Harrisburg, PA: State Printer of Pennsylvania, 1896-1976.

Webster, Pelatiah, Political Essays on the Nature and Operation of Money, Public Finances and Other Objects. New York: Burt Franklin, 1969.

West, Roger Craig, "Money in the Colonial American Economy." Economic Inquiry 16 (Jan. 1978), pp. 1-15.

Wicker, Elmus, 'Colonial Monetary Standards Contrasted: Evidence from the Seven Years' War." Journal of Economic History 45 (Dec. 1985), pp. 869-884. 
TABLE 1. Replication of Results in West (1978) for Pennsylvania, 1723-1775

I. Replication of Results in West (1978, p. 4) for Pennsylvania $\quad \begin{aligned} & \text { Regres- Total } \\ & \text { sion } \mathrm{R}^{2}\end{aligned} \mathrm{R}^{2} \quad D W$

\section{A. Results Reported by West (1978, p. 4) Using Only Mp for 1723-1774:}

$$
\begin{aligned}
& \ln \left(\mathrm{PI}_{(\mathrm{i})}\right)=5.10^{* * *}-0.02 \ln \left(\mathrm{Mp}_{(\mathrm{i})}\right) \\
& \text { (0.63) (0.07) } \\
& \ln \left(\mathrm{PI}_{(\mathrm{i})}\right)=4.31^{* * *}-0.04 \ln \left(\mathrm{Mp}_{(\mathrm{i})}\right)+0.09 \ln \left(\mathrm{Mp}_{(\mathrm{i}-1)}\right) \\
& (0.70) \quad(0.06) \quad(0.06) \\
& \begin{array}{ccccc}
\ln \left(\mathrm{PI}_{(\mathrm{i})}\right)= & 3.42^{* * *}-0.02 \ln \left(\mathrm{Mp}_{(\mathrm{i})}\right)+0.08 \ln \left(\mathrm{Mp}_{(\mathrm{i}-1)}\right)+0.06 \ln \left(\mathrm{Mp}_{(\mathrm{i}-2)}\right) & 0.13 & - & \\
(0.63) & (0.07) & (0.05) & (0.05)
\end{array}
\end{aligned}
$$

\section{B. Replication of These Results Using the Same Data and Model: ${ }^{\text {a }}$}

$$
\begin{aligned}
& \begin{array}{c}
\ln \left(\mathrm{PI}_{(\mathrm{i})}\right)=4.29^{* * *}+0.04 \ln \left(\mathrm{Mp}_{(\mathrm{i})}\right) \\
(0.42) \quad(0.04)
\end{array}
\end{aligned}
$$

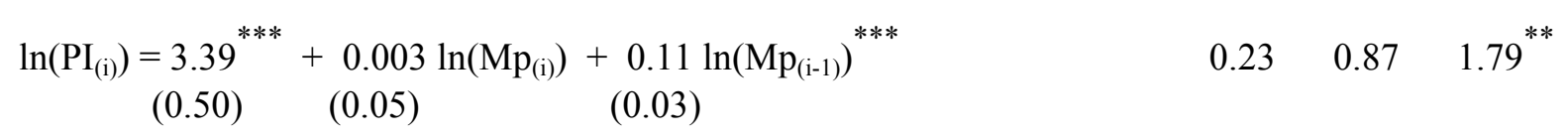

$$
\begin{aligned}
& \begin{array}{cccccc}
\ln \left(\mathrm{PI}_{(\mathrm{i})}\right)=3.37^{* * *}-0.01 \ln \left(\mathrm{Mp}_{(\mathrm{i})}\right)+0.10 \ln \left(\mathrm{Mp}_{(\mathrm{i}-1)}\right) & +0.03 \ln \left(\mathrm{Mp}_{(\mathrm{i}-2)}\right) & 0.14 & 0.87 & 1.81^{* *} \\
(0.57) & (0.05) & (0.06) & (0.04)
\end{array}
\end{aligned}
$$

II. Results of the West (1978, p. 4) Style Model Using MT [= Mp + Ms] for Pennsylvania 1729-1775

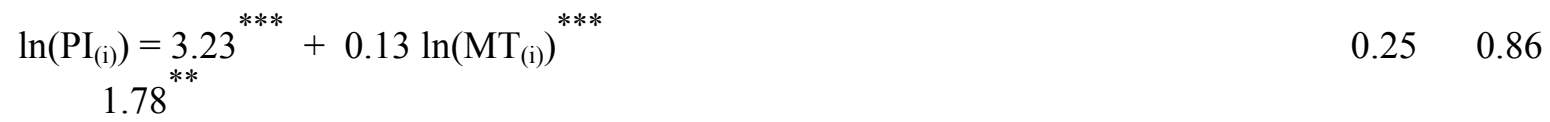

$$
\begin{aligned}
& (0.44) \quad(0.04)
\end{aligned}
$$

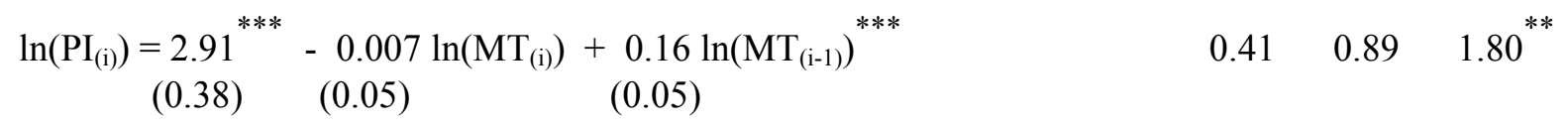

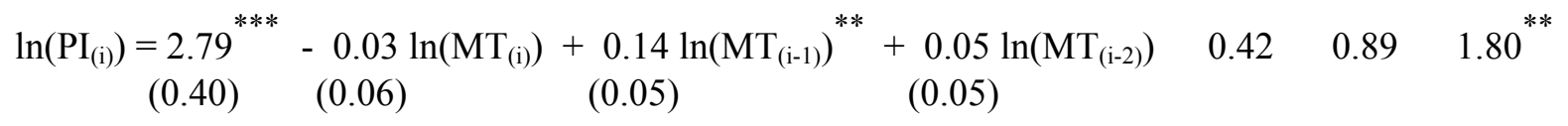

${ }^{* * *}$ Statistically significant above the 0.01 level.

** Statistically significant above the 0.05 level.

* Statistically significant above the 0.10 level. 
${ }^{a}$ Coefficient magnitudes and significance levels are not changed when using data for the years 1729-1775.

Notes: Standard errors are in parentheses. The $\mathrm{R}^{2} \mathrm{~s}$ reported by West $(1978, \mathrm{p} .4)$ are assumed to be Regression $\mathrm{R}^{2} \mathrm{~s}$. All results are AR2 error corrected for serial correlation. See Appendix-Table A and text for variable definitions.

Sources: Appendix-Table A; West (1978, pp. 2-5). 
TABLE 2. Replication of Results in Smith (1985b) for Maryland, 1735-1764

I. Replication of Results in Smith $(\mathbf{1 9 8 5 b}, \mathbf{p .} 1, \mathbf{2 0 7})$ for Maryland $\begin{aligned} & \text { Regres- Total } \\ & \text { sion } \mathbf{R}^{2}\end{aligned} \quad \begin{aligned} & \mathrm{R}^{2} \\ & D W\end{aligned}$

A. Results Reported by Smith (1985b, p. 1,207):

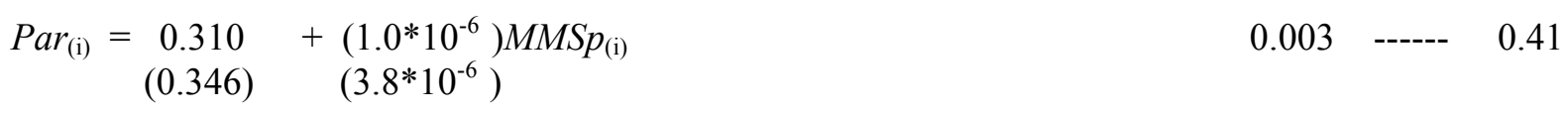

$$
\begin{aligned}
& \operatorname{Par}_{(\mathrm{i})}=\begin{array}{ccc}
0.840^{* *} \\
(0.412) & \left(1.0^{*} 10^{-7}\right) M M S p_{(\mathrm{i})}-0.910\left(F_{(i)} / F_{(1764)}\right) & 0.364
\end{array}
\end{aligned}
$$

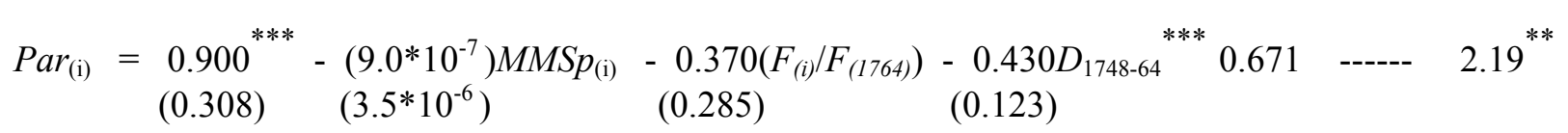

B. Replication of These Results Using the Same Data and Model: ${ }^{\text {a }}$

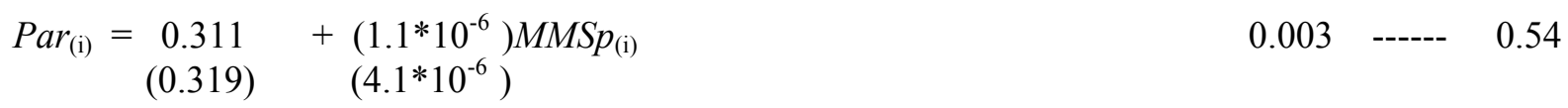

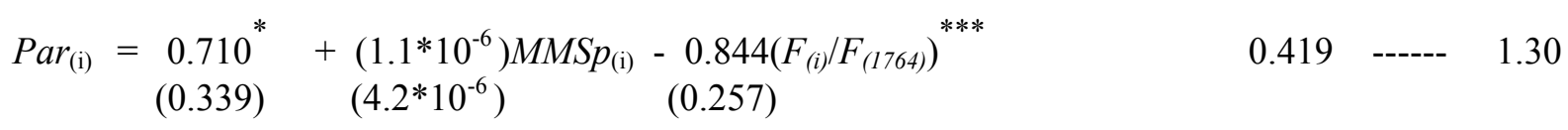

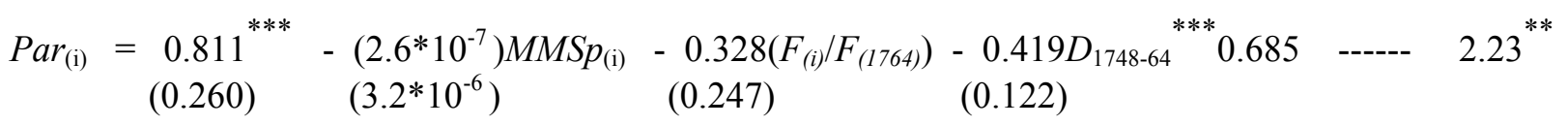

C. Replication of These Results Using the Same Data and Model but for Different Ds:

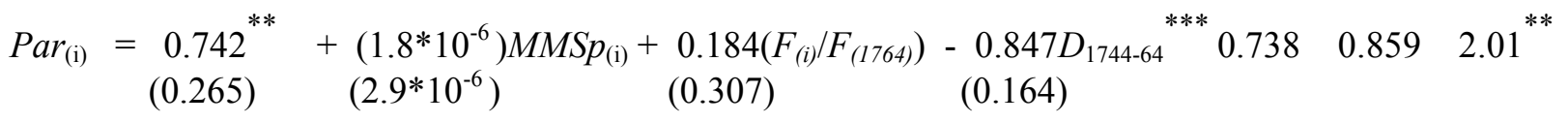

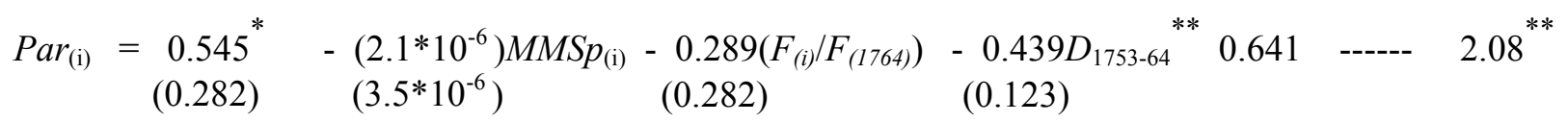

II. The Smith Model Using Alternative Interpolated Values and Backing Measures: ${ }^{\text {b }}$

A. Results Using Smith's (1985b, p. 1,207) Measure of Backing $\left(F_{(i)} / F_{(1764)}\right)$ :

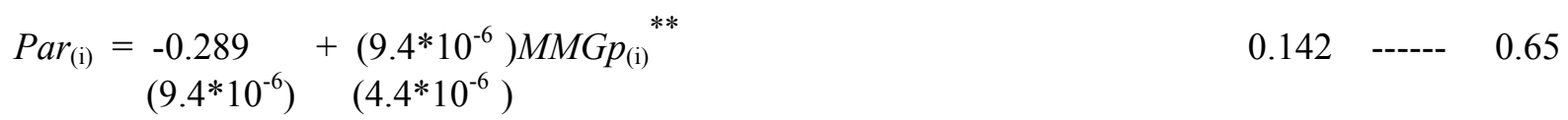

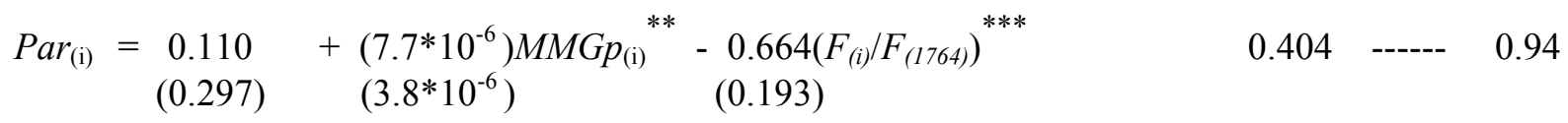

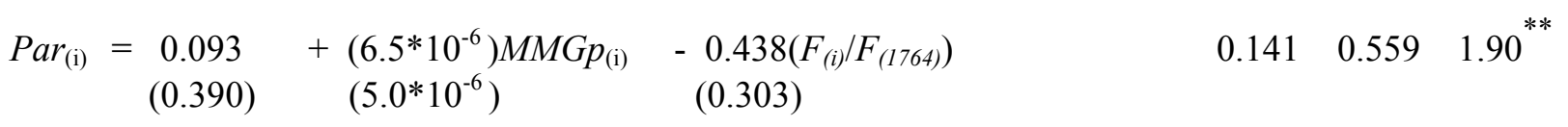




\section{B. Results Using an Alternative Rational Expectations Measure of Backing:}

$$
\begin{aligned}
& \operatorname{Par}_{(\mathrm{i})}=-0.421+\left(9.5^{*} 10^{-6}\right) M M G p_{(\mathrm{i})}{ }^{* *}+0.024 \text { Forecasted Backing }_{(\mathrm{i})}{ }^{* *} \quad 0.289------0.84 \\
& (0.303) \quad\left(4.1 * 10^{-6}\right) \quad(0.010)
\end{aligned}
$$

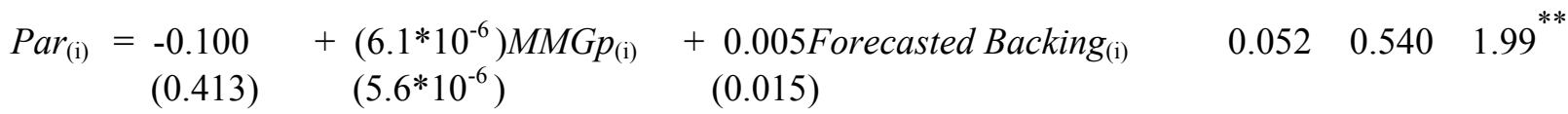

${ }^{* * *}$ Statistically significant above the 0.01 level.

** Statistically significant above the 0.05 level.

* Statistically significant above the 0.10 level.

${ }^{a}$ The slight difference in results is most likely due to how missing values were handled by the estimation programs.

${ }^{b}$ These interpolated values are reported in the brackets and their construction is described in the notes of Appendix-Table B.

Notes: Standard errors are in parentheses. When Total $\mathrm{R}^{2}$ is reported this means that the results are AR1 error corrected for serial correlation. Par is defined as the percentage the exchange rate $(e)$ is below the relevant redemption rate, where the redemption rate is 1.0 Maryland pound equals 0.75 pounds sterling and $e$ is defined as the "sterling value of a Maryland pound note" (Smith, 1985b, p. 1,201). Thus, Par equals [(0.75/e) - 1], which in turn equals $\left[\left(E x^{*} 0.0075\right)-1\right]$ because $e$ equals $(100 / E x)$, where $E x$ is the exchange rate taken from McCusker (1978, pp. 202-03), see footnote 10 and Appendix-Table B. MMSp equals Smith's interpolation of the quantity of Maryland pounds (bills of credit) in circulation. $M M G p$ equals my interpolation of the quantity of Maryland pounds in circulation. $\left(F_{(i)} / F_{(1764)}\right)$ equals the value of the sinking fund as a percentage of its value in 1764 which was its terminal and maximum value. $D$ equals one for the years indicated and zero otherwise. Forecasted Backing equals the 
percentage by which the actual sinking funds accumulated at a given date falls below the linear accumulation rate, from 1733 through 1764, needed to fulfill the promised redemption in 1764 .

Sources: Appendix—Table B; Brock (1975, pp. 104-05, 417-22); Smith (1985b). 
FIGURE 1. The Growth in Real Money Balances Per Capita: Pennsylvania, 1729-1775

Notes: See Appendix-Table A for variable definitions. All nominal values are expressed in Pennsylvania pounds. For $M T,[\ln (M)-\ln (P)-\ln (P o p)]=[\ln (Y)-\ln (V)-\ln (P o p)]$.

Source: Appendix-Table A.

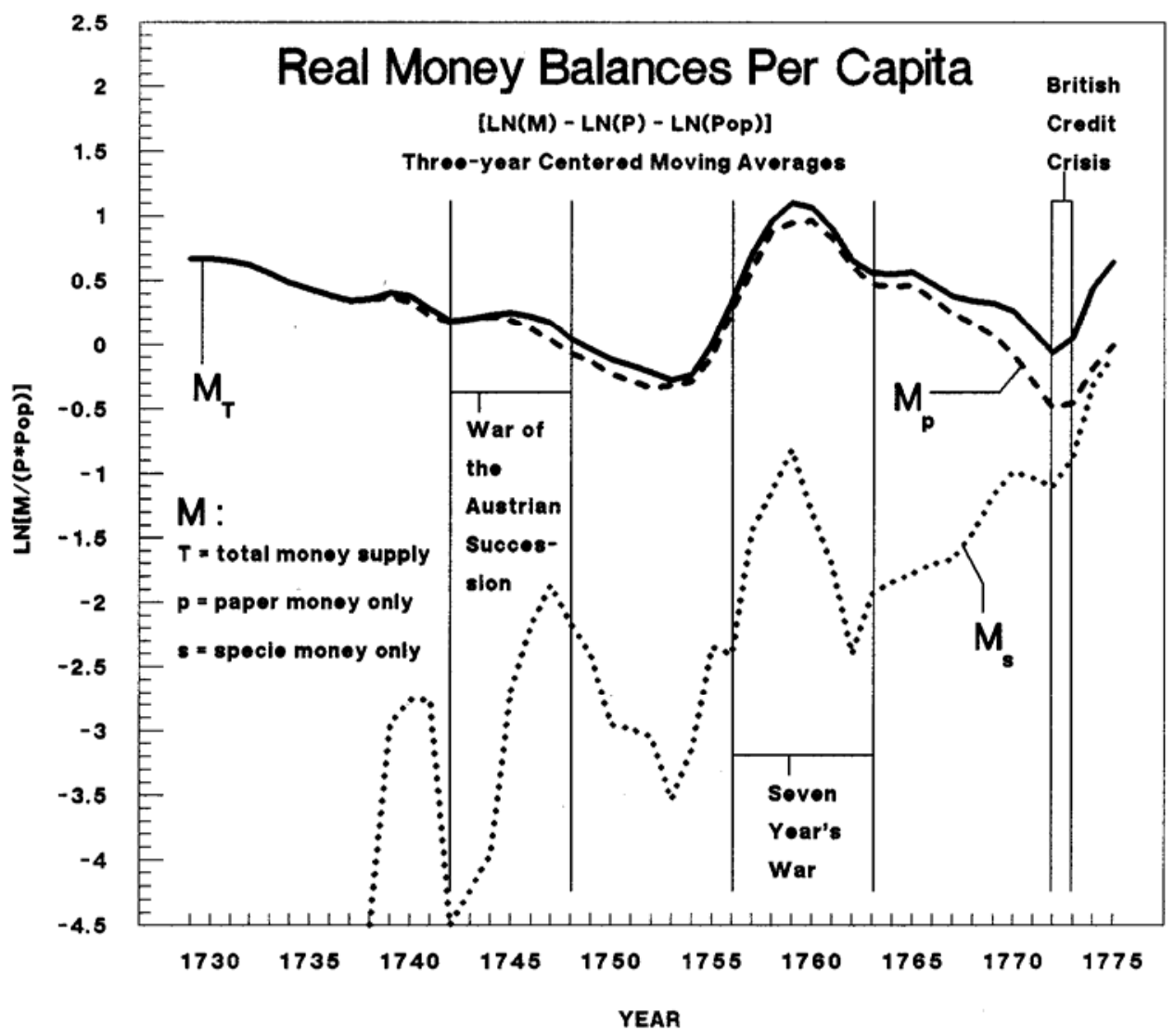


APPENDIX - TABLE A. The Data for Pennsylvania, 1723-1775

\begin{tabular}{|c|c|c|c|c|c|c|c|}
\hline Year & $\begin{array}{l}\text { Outstanding } \\
\text { Pennsylvania } \\
\text { Paper Pounds } \\
\quad[M p]\end{array}$ & $\begin{array}{l}\text { Ratio: } \\
\text { Specie } \\
\text { to } \\
\text { Paper }\end{array}$ & $\begin{array}{l}\text { Implied } \\
\text { Total } \\
\text { Specie } \\
{[M s]}\end{array}$ & $\begin{array}{l}\text { Total Currency } \\
\text { in Circulation } \\
(M p+M s) \\
{[M T]}\end{array}$ & $\begin{array}{l}\text { Pennsylvania } \\
\text { Population } \\
{[\text { Pop }]}\end{array}$ & $\begin{array}{l}\text { Price } \\
\text { Index } \\
{[P I]}\end{array}$ & $\begin{array}{l}\text { Average Current } \\
\text { Commodity Price } \\
\text { in PA Pounds } \\
{[P]}\end{array}$ \\
\hline 1723 & 15,000 & ---- & ---- & ---- & 37,182 & 89.2 & 0.6199 \\
\hline 1724 & 44,915 & ---- & ---- & ---- & 39,257 & 95.9 & 0.6665 \\
\hline 1725 & 38,915 & ---- & ---- & ---- & 41,332 & 110.5 & 0.7680 \\
\hline 1726 & 38,890 & ---- & ---- & ---- & 43,407 & 110.8 & 0.7701 \\
\hline 1727 & 38,890 & ---- & ---- & ---- & 45,482 & 107.8 & 0.7492 \\
\hline 1728 & 38,890 & ---- & ---- & ---- & 47,557 & 101.6 & 0.7061 \\
\hline 1729 & 68,890 & 0.0000 & 0 & 68,890 & 49,632 & 99.2 & 0.6903 \\
\hline 1730 & 68,890 & 0.0000 & 0 & 68,890 & 51,707 & 101.9 & 0.7090 \\
\hline 1731 & 68,890 & 0.0000 & 0 & 68,890 & 55,100 & 91.4 & 0.6360 \\
\hline 1732 & 68,890 & 0.0000 & 0 & 68,890 & 58,493 & 89.9 & 0.6255 \\
\hline 1733 & 68,890 & 0.0000 & 0 & 68,890 & 61,886 & 92.6 & 0.6443 \\
\hline 1734 & 68,890 & 0.0000 & 0 & 68,890 & 65,279 & 95.0 & 0.6610 \\
\hline 1735 & 68,890 & 0.0000 & 0 & 68,890 & 68,672 & 95.0 & 0.6610 \\
\hline 1736 & 68,890 & 0.0000 & 0 & 68,890 & 72,065 & 90.5 & 0.6297 \\
\hline 1737 & 68,890 & 0.0000 & 0 & 68,890 & 75,458 & 94.7 & 0.6589 \\
\hline 1738 & 68,890 & 0.0000 & 0 & 68,890 & 78,851 & 95.2 & 0.6624 \\
\hline 1739 & 80,000 & 0.0000 & 0 & 80,000 & 82,244 & 88.9 & 0.6179 \\
\hline 1740 & 80,000 & 0.1071 & 8,571 & 88,571 & 85,637 & 91.1 & 0.6402 \\
\hline 1741 & 80,000 & 0.0286 & 2,286 & 82,286 & 89,040 & 111.5 & 0.7758 \\
\hline 1742 & 80,000 & 0.0000 & 0 & 80,000 & 92,443 & 108.5 & 0.7550 \\
\hline 1743 & 80,000 & 0.0000 & 0 & 80,000 & 95,846 & 94.8 & 0.6596 \\
\hline 1744 & 80,000 & 0.0000 & 0 & 80,000 & 99,249 & 92.2 & 0.6415 \\
\hline 1745 & 80,000 & 0.0476 & 3,810 & 83,810 & 102,652 & 93.0 & 0.6471 \\
\hline 1746 & 85,000 & 0.1250 & 10,625 & 95,625 & 106,055 & 98.2 & 0.6832 \\
\hline 1747 & 85,000 & 0.1311 & 11,148 & 96,148 & 109,458 & 109.5 & 0.7619 \\
\hline 1748 & 85,000 & 0.2000 & 17,000 & 102,000 & 112,861 & 119.7 & 0.8329 \\
\hline 1749 & 85,000 & 0.0339 & 2,881 & 87,881 & 116,264 & 120.3 & 0.8370 \\
\hline 1750 & 84,500 & 0.0685 & 5,788 & 90,288 & 119,666 & 120.0 & 0.8349 \\
\hline 1751 & 84,000 & 0.0870 & 7,304 & 91,304 & 126,070 & 120.8 & 0.8405 \\
\hline 1752 & 83,500 & 0.0326 & 2,723 & 86,223 & 132,474 & 121.0 & 0.8419 \\
\hline 1753 & 82,500 & 0.0674 & 5,562 & 88,062 & 138,878 & 117.9 & 0.8204 \\
\hline 1754 & 81,500 & 0.0202 & 1,646 & 83,146 & 145,282 & 114.4 & 0.7960 \\
\hline 1755 & 96,000 & 0.0805 & 7,724 & 103,724 & 151,686 & 111.7 & 0.7772 \\
\hline 1756 & 147,510 & 0.1714 & 25,287 & 172,797 & 158,090 & 111.7 & 0.7772 \\
\hline 1757 & 247,013 & 0.0000 & 0 & 247,013 & 164,494 & 112.5 & 0.7828 \\
\hline 1758 & 312,859 & 0.2222 & 69,524 & 382,383 & 170,897 & 115.4 & 0.8029 \\
\hline 1759 & 422,911 & 0.1667 & 70,485 & 493,396 & 177,300 & 127.4 & 0.8865 \\
\hline 1760 & 446,158 & 0.1351 & 60,292 & 506,450 & 183,703 & 128.2 & 0.8920 \\
\hline 1761 & 408,972 & 0.0000 & 0 & 408,972 & 189,338 & 127.3 & 0.8858 \\
\hline 1762 & 320,676 & 0.1042 & 33,404 & 354,080 & 194,973 & 140.1 & 0.9748 \\
\hline 1763 & 264,460 & 0.0698 & 18,451 & 282,911 & 200,608 & 137.5 & 0.9568 \\
\hline 1764 & 316,082 & 0.0930 & 29,403 & 345,485 & 206,243 & 126.9 & 0.8829 \\
\hline 1765 & 305,095 & 0.1341 & 40,927 & 346,022 & 211,878 & 126.9 & 0.8829 \\
\hline 1766 & 281,431 & 0.0916 & 25,780 & 307,211 & 217,513 & 133.1 & 0.9261 \\
\hline
\end{tabular}




\begin{tabular}{llllllll}
1767 & 258,420 & 0.1585 & 40,969 & 299,389 & 223,149 & 132.5 & 0.9219 \\
1768 & 233,934 & 0.2048 & 47,914 & 281,848 & 228,785 & 126.0 & 0.8767 \\
1769 & 220,911 & 0.2300 & 50,810 & 271,721 & 234,421 & 122.1 & 0.8496 \\
1770 & 201,173 & 0.4697 & 94,490 & 295,663 & 240,057 & 128.4 & 0.8934 \\
1771 & 171,871 & 0.5634 & 96,829 & 268,700 & 248,782 & 133.2 & 0.9268 \\
1772 & 149,115 & 0.3596 & 53,614 & 202,729 & 257,507 & 147.2 & 1.0242 \\
1773 & 135,006 & 0.7191 & 97,083 & 232,089 & 266,232 & 141.5 & 0.9845 \\
1774 & 217,633 & 0.8193 & 178,302 & 395,935 & 274,957 & 137.7 & 0.9581 \\
1775 & 318,613 & 0.9872 & 314,528 & 633,141 & 283,682 & 140.9 & 0.9662 \\
\hline
\end{tabular}

Notes: All nominal values are expressed in Pennsylvania pounds. For population estimates linear interpolation between the decadal data points is used. Implied Total Specie $=$ $[($ Ratio: Specie to Paper $) *($ Outstanding Pennsylvania Paper Pounds $)]$, i.e., $M s=M s / M p * M p$. This method assumes that the velocity of circulation of paper money $(V p)$ equals the velocity of circulation of specie $(V s)$. Thus, in the quantity theory of money formation (Fisher 1912): $\left[M p^{*} V p+M s^{*} V s\right]=[M p+M s]^{*} V=M T^{*} V$. The Average Current Commodity Price is taken from the 20 commodity unweighted arithmetic price index for Philadelphia [base year equal to 1741-45] reported in Bezanson, et al. (1935, pp. 429, 433). This price index is converted to the Average Current Commodity Price in PA Pounds by multiplying the index number by the summation of the 20 commodity prices for the base year, dividing this number by 100 , dividing this number by 20 (the number of commodities), and then dividing this number by 20 (to convert shillings to pounds).

Sources: The data on outstanding Pennsylvania pounds are taken from Brock (1975, pp. $82-83,386-87 ; 1992$, p. 113); the ratio of specie to paper currency from Grubb (2004); the Pennsylvania population from Historical Statistics (1975, part 2, p. 1,168); and commodity prices from Bezanson, et al. (1935, pp. 429, 433). 
APPENDIX - TABLE B. The Data for Maryland, 1735-1764

\begin{tabular}{|c|c|c|c|c|}
\hline Year & $\begin{array}{l}\text { Outstanding Notes } \\
\text { in Circulation in } \\
\text { Maryland Pounds: } \\
\text { Smith Interpolations } \\
{[M M S p]}\end{array}$ & $\begin{array}{l}\text { Outstanding Notes } \\
\text { in Circulation in } \\
\text { Maryland Pounds: } \\
\text { Grubb Interpolations } \\
{[M M G p]}\end{array}$ & $\begin{array}{l}\text { Face Value of } \\
\text { Sinking Fund } \\
\text { in Pounds } \\
\text { Sterling } \\
{[F]}\end{array}$ & $\begin{array}{l}\text { Exchange Rate: } \\
\text { Number of Maryland } \\
\text { Pounds Needed to Buy } \\
100 \text { Pounds Sterling } \\
{[E x]}\end{array}$ \\
\hline 1735 & 56,495 & 56,495 & {$[1,334]$} & 140.00 \\
\hline 1736 & 57,864 & 57,864 & 2,000 & 230.00 \\
\hline 1737 & 69,856 & 69,856 & 4,000 & 250.00 \\
\hline 1738 & {$[69,856]$} & {$[74,838]$} & {$[5,000]$} & 225.00 \\
\hline 1739 & 79,820 & 79,820 & 6,000 & 212.34 \\
\hline 1740 & 78,523 & 78,523 & 7,500 & 228.08 \\
\hline 1741 & 83,444 & 83,444 & 9,500 & 238.17 \\
\hline 1742 & 82,072 & 82,072 & {$[11,000]$} & 275.00 \\
\hline 1743 & {$[82,252]^{*}$} & {$[82,162]$} & 12,500 & 285.13 \\
\hline 1744 & $83,058^{*}$ & 82,252 & 15,000 & 166.67 \\
\hline 1745 & 83,058 & 83,058 & {$[16,900]$} & 200.00 \\
\hline 1746 & {$[83,058]$} & {$[84,184]$} & 18,800 & 210.00 \\
\hline 1747 & 85,309 & 85,309 & 21,000 & 225.22 \\
\hline 1748 & 86,040 & 86,040 & 24,000 & 200.61 \\
\hline 1749 & {$[62,000]^{* *}$} & {$[62,000]^{* *}$} & 12,000 & 184.58 \\
\hline 1750 & {$[62,000]$} & {$[62,000]$} & {$[11,500]$} & 177.92 \\
\hline 1751 & {$[62,000]$} & {$[62,000]$} & 11,000 & 166.83 \\
\hline 1752 & {$[62,000]$} & {$[62,000]$} & {$[13,500]$} & 155.62 \\
\hline 1753 & {$[62,000]$} & {$[62,000]$} & 16,000 & 151.75 \\
\hline 1754 & {$[62,000]$} & {$[62,000]$} & {$[17,750]$} & 153.75 \\
\hline 1755 & {$[62,000]$} & {$[62,003]$} & 19,500 & [161.88] \\
\hline 1756 & {$[96,017]$} & {$[70,507]^{* * *}$} & {$[19,500]$} & 170.00 \\
\hline 1757 & {$[96,017]$} & {$[79,011]$} & 19,500 & 145.00 \\
\hline 1758 & {$[96,017]$} & {$[87,515]$} & 19,500 & 150.00 \\
\hline 1759 & {$[96,017]$} & {$[96,018]$} & {$[23,500]$} & 150.00 \\
\hline 1760 & {$[96,017]$} & {$[85,074]$} & 27,500 & 146.25 \\
\hline 1761 & {$[96,017]$} & {$[74,130]$} & {$[31,500]$} & 148.48 \\
\hline 1762 & {$[96,017]$} & {$[63,186]$} & 35,500 & 144.45 \\
\hline 1763 & {$[62,000]$} & {$[52,242]$} & {$[38,150]$} & 140.00 \\
\hline 1764 & 41,295 & 41,295 & 40,800 & 136.67 \\
\hline
\end{tabular}

* These values are transcription errors by Smith (1985b, pp. 1,204-05) from the original source.

** The original source states that in 1749 “...there were some 62,000 in bills, new and old, in circulation" and that no new bills were issued until 1756 (Brock 1975, pp. 104, 418). 
$* * *$ The original source states that the 40,000 in new bills authorized in 1756 “...were not thrown at once into Circulation but paid out from time to time to the Troops...", that total bills in circulation reached a peak of 96,018, and that "By October, 1763, the sums arising from the various taxes had proved more than sufficient to retire the 30,000 in new bills issued by the act of 1756 , together with the 4,015 in unexchanged conversion bills that had been paid out." (Brock 1975, pp. 418-19).

Notes: Where data were missing in the original sources, interpolated values are substituted in brackets. Simple linear interpolations are used throughout except for [MMGp] between 1756 and 1764. The interpolation for these years is derived from the statements in the above notes. Smith (1985b, pp. 1,204-05) provided no interpolated values for $[F]$ and $[E x]$, but instead left these values blank. Thus, they were treated as missing values in the replication of his econometric results in Table 4 -Section I, Parts B and C. His interpolated values for $[M M S p]$ appear to be a combination of filling in missing values with their immediate prior observation for observations before 1749, and substituting "authorized" amounts for the amounts actually in circulation for observations after 1755 . For $[E x]$ par was defined to be 133.33 , or one Maryland pound equaled 0.75 pounds sterling.

Sources: $[M M S p]$ and $[F]$ are taken from Smith (1985b, pp. 1,204-05). [MMGp] and $[M M S p]$ are derived from original data in $\operatorname{Brock}(1975, \mathrm{pp} .104-05,417-22) .[E x]$ is from McCusker (1978, pp. 202-03). 


\section{Footnotes:}

${ }^{1}$ The modern protagonists in this debate have added little new or original to the arguments that were prevalent and well articulated among the colonists themselves, other than the translation of these arguments into modern pedagogy (for just a few of the many examples, see Archives of State of New Jersey, 1st series, vol. 5, pp. 120-22, 156-57; Davis 1964, vol. 4, 377-405; Ernst 1973, pp. 63-64; Marchione 1983, pp. 325-30; various editorials on money in the Maryland Gazette between 1780 and 1782 and in the Pennsylvania Gazette between 1739 and 1760; Newell 1998, pp. 130-31, 145-46, 214-35; Nussbaum 1957, p. 27; Pennsylvania Archives, 8th series, vol. 6, pp. 4516-30; Perkins 1991; Webster 1969, pp. 139-61). The contribution of the modern protagonists in this debate is applied. They selectively marshaled the evidence gathered by other scholars long ago to support their respective theoretical positions. They, however, undertook no econometric estimation or statistical testing, with the notable exception of Smith's (1985b) work on 1735-1764 Maryland — which will be addressed below.

2 The post-West (1978) quantitative studies of colonial monetary performance cover the colonies of South Carolina, North Carolina, Virginia, Maryland, Pennsylvania, New Jersey, New York, Rhode Island, and Massachusetts (McCallum 1992; Michener 1987; Smith 1985a, 1985b, 1988; Wicker 1985). All of these studies, however, are non-econometric and provide no statistical testing, with the one exception noted in footnote 1 . In addition, price data were not used, because reliable price data do not exist, for North Carolina, Virginia, Maryland, New Jersey, and Rhode Island. Finally, none of these studies have information on the specie component of the yearly money supply. 
${ }^{3}$ Several reasons account for why my replication of West's (1978) model differs from his original results. West used the Bezanson (1935) price index as reproduced in Cole (1938). I used the original price index as reported in Bezanson that differed from that reproduced in Cole by being carried to one more decimal place. West used the Brock (1975) data on paper money. I used the Brock (1992) data on paper money that corrected Brock's earlier data for minor errors. Finally, West used Cochrane-Orchutt while I used the more efficient Yule-Walker technique to correct for serial correlation.

${ }^{4}$ The average price rather than the price index is used because the difference between the natural logarithm of the index and that of its average price is almost imperceptible, i.e., yielding less than a 0.0002 and 0.000005 difference in the coefficient and standard error on the variable $t$, respectively. By using the average price the actual current total-real-money-balance per capita in Pennsylvania pounds can be easily calculated by taking $e^{m}$ for that year. $t=($ Year -1728$)$. The results also do not perceptibly change when using slightly different sample end points, i.e., 17301775 and 1729-1774.

${ }^{5}$ When using Dickey-Fuller critical values for $m_{(\mathrm{i}-1)}$ and the Dickey-Fuller F-test, nonstationarity is rejected. See Enders (1995, pp. 221-23, 257, 419, 421).

6 The variant of the quantity theorists' model that relies on merchants to maintain the fixed exchange rate between paper and specie right up to the point where all specie disappears from the colony (Michener 1987, p. 264) is inconsistent with rational expectations. Given an increase in the quantity of paper money by the legislature, merchants would revise their expected probability that the legislature might in the near future continue this practice and so drive the 
colony over the zero-specie threshold. Given this increased expected likelihood, merchants would begin to demand higher prices in paper money per unit of specie well before the zerospecie threshold was reached, and vice versa. A rational expectations mechanism of monetary adjustment by merchant arbitragers would lead to a variable exchange rate between paper and specie even when considerable specie was still in circulation in the colony. Thus, paper and specie would be less than perfect substitutes, and the door would be opened to changes in the quantity of paper money affecting prices even when specie was in circulation.

${ }^{7}$ All reported correlation coefficients are statistically different from zero above the 0.02 significance level.

${ }^{8}$ The colonial institutional setting is somewhat reminiscent of the system proposed by Friedman (1948). It should be noted at this juncture that this institutional linking of $V$ and $M T$ is also not a violation of the general quantity theory of money $\left(M T^{*} V=P^{*} Y\right)$ or the "equation of exchange" as Fisher (1912) called it. The classical assumption that $V$ is not a direct function of $M T$ is derived from the particular monetary institutional settings of the 19th and early 20th centuries where $M T$ is a function of a loosely regulated fractional-reserve private banking system (Fisher 1912, Laidler 1987). Most quantity theorists would agree that $V$ not being a direct function of $M T$ is neither a universal nor institutionally-invariant condition. Because the colonial economy had no banks, no fractional reserve banking, no demand or time deposits, no mints for coinage, no government bonds, and so forth, the colonial world was clearly different enough to warrant relaxing the classical assumption that $V$ is not a direct function of $M T$.

${ }^{9}$ In this period, Maryland occasionally issued a small number of additional bills of credit that 
were backed, as other colonies backed their bills, through future taxes and land mortgages, and not by a sinking fund whose current value was directly measurable. See Brock (1975, pp. 99$105,412-28)$.

${ }^{10}$ Smith (1985b, pp. 1201-05) states that $e$ denotes the sterling value of a Maryland pound note, that the redemption rate is four Maryland pounds for three pounds sterling, that Par $=.75 e$ -1 , that Par is the percentage the exchange rate is above the relevant redemption rate, and that the exchange rate $(E x)$ is the number of Maryland pounds per 100 pounds sterling (AppendixTable B). These statements are mutually inconsistent, and if followed exactly cannot replicate his econometric results. It appears that Smith's statement that $[\operatorname{Par}=.75 e-1]$ is erroneous. It should be $[P a r=.75 / e-1]$ which in turn equals $\left[\left(E x^{*} 0.0075\right)-1\right]$ because $e$ equals $(100 / E x)$. If $[P a r=.75 / e-1]$ is used, then Smith's econometric results can be replicated. This also implies that Par is the percentage that $e$ is below the relevant redemption rate.

11 The same results are found for all subsequent models estimated in Table 2. In addition, the standard Chow Test cannot reject the absence of a structural break at $1748(F$-statistic $=2.28)$. The Chow Test is only relevant when using the correctly specified data and variable construction, i.e., the last regression reported in Table 2. Dickey-Fuller tests show that from 1735 through 1765 both Par and $\ln (E x)$ are trend-stationary, and Perron (1989, pp. 1380-83) tests show a structural break in these trend-stationary processes at 1748 . However, the same results are found when the break is modeled to be either in 1749,1750 , or 1743 . These results are available from the author upon request, or the reader can replicate them directly using the data in Appendix - Table B. Finally, even if there were structural breaks in Par and $\ln (E x)$ at 1748, it would be impossible to distinguish between whether such breaks were caused by 
Maryland's successful currency redemption or by the shock to real trade flows occasioned by the end of the War of the Austrian Succession. In conclusion, Smith's (1985b) dummy variable measure of backing [ $\left.D_{1748-64}\right]$ lacks both statistical and interpretive relevance.

12 Tobacco exports grew at under $0.5 \%$ per year between 1727 and 1770 . Derived from Historical Statistics (1975, part 2, pp. 1189-90). See also McCusker and Menard 1985, p. 121. On commission fees, see Price (1977).

${ }^{13}$ Inspection of the Maryland exchange rate data (McCusker 1978, pp. 202-03) indicates that substantial measurement error may be present. The yearly exchange rate in many cases is derived from only a single observation in a particular merchant account book, and said observations across years are derived from different merchants reporting at different times of the year.

${ }^{14}$ For example, the Currency Acts of 1751 and 1764 imposed on the colonies by Parliament did not produce effective backing regime shifts in most colonies. These acts required that colonial paper money not be made legal tender and that future taxes be put in place to redeem said paper money in a timely fashion (Ernst 1973, Wicker 1985, Grubb 2003). Most colonies, such as Maryland, Pennsylvania, and New York, had been backing and redeeming their paper money with explicit future taxes long before these acts. The removal of paper money's legal tender status by these acts also did not produce an effective regime shift. Because colonial legislatures had and continued to accept their own paper money in payment of the taxes they imposed and land mortgages they held, their paper money had de facto legal tender status for public debts. This, in turn, served as an effective nominal anchor for its use as a tender for private debts. 
